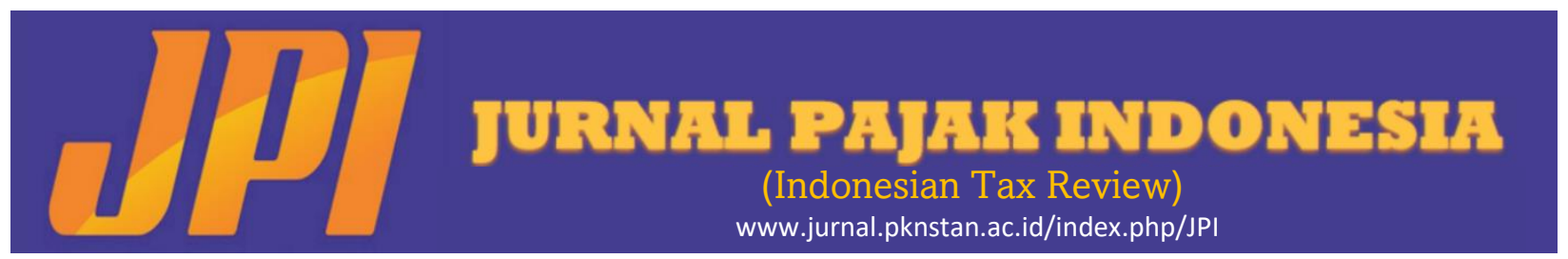

\title{
PPN ATAS PENYERAHAN BATU BARA DALAM UNDANG-UNDANG CIPTA KERJA (Menakar Potensi Kenaikan atau Penurunannya terhadap Penerimaan Negara)
}

\author{
Nabila Adriyani Putri \\ Politeknik Keuangan Negara STAN \\ Imam Muhasan \\ Politeknik Keuangan Negara STAN
}

Alamat Korespondensi: nabilaadriyani@gmail.com; imam.muhasan@pknstan.ac.id

INFORMASI ARTIKEL
Diterima Pertama
20 Juli 2021
Dinyatakan Diterima
20 Juli 2021
KATA KUNCI:
Pajak Pertambahan Nilai, Batu Bara, UU Cipta
Kerja, Restitusi, Penerimaan Negara

INFORMASI ARTIKEL

Diterima Pertama

Kerja, Restitusi, Penerimaan Negara

\section{ABSTRAK}

With the enactment of Law Number 11 of 2020 on Job Creation, coal is exclusively excluded from the negative list of Taxable Goods. In other words, based on the Job Creation Law, coal becomes Taxable Goods. At first glance, the qualification of coal as Taxable Goods, which is subject to Value Added Tax (VAT), will increase state revenues from the coal VAT sector. However, considering that coal is a mainly export-oriented commodity, qualifying coa as Taxable Goods may have the potential to reduce state revenues because there are opportunities for coal entrepreneurs to apply for VAT refunds. This is considering that by becoming Taxable Goods, the Input Tax on coal exploitation becomes creditable. While the Output Tax for Taxable Goods exports, the VAT rate imposed is $0 \%$. The main problem in this research is whether the inclusion of coal in the Taxable Goods category will automatically have the potential to increase state revenues or vice versa? Using the simulation numbers of coal companies listed on the IDX, what is the potential increase or decrease? This research was conducted through a literature study analyzing laws and regulations and secondary data simulation with a qualitative descriptive approach. The results show that the inclusion of coal as Taxable Goods can cause a decrease in state revenues, with an average value of around 5.3 trillion rupiahs per year.

Dengan telah diundangkannya Undang-Undang Nomor 11 Tahun 2020 tentang Cipta Kerja, batu bara secara eksklusif dikecualikan dari negative list Barang Kena Pajak (BKP). Dengan kata lain, berdasarkan UU Cipta Kerja, batu bara menjadi BKP. Selintas, pengualifikasian batu bara sebagai BKP yang oleh karenanya atas penyerahannya menjadi terutang Pajak Pertambahan Nilai (PPN) akan meningkatkan penerimaan negara dari sektor PPN batu bara. Namun demikian, mengingat bahwa batu bara merupakan komoditas yang sebagian besar berorientasi ekspor, tidak tertutup kemungkinan pengualifikasian batu bara sebagai BKP ini justru berpotensi menurunkan penerimaan negara karena adanya peluang bagi pengusaha batu bara untuk mengajukan restitusi PPN. Hal ini mengingat bahwa dengan menjadi BKP, Pajak Masukan atas pengusahaan batu bara menjadi dapat dikreditkan. Sementara Pajak Keluaran atas untuk ekspor $B K P$, tarif PPN yang dikenakan adalah 0\%. Pokok permasalahan dalam penelitian ini adalah apakah dengan dimasukkannya batu bara dalam kategori BKP otomatis akan berpotensi pada kenaikan penerimaan negara atau justru sebaliknya? Dengan menggunakan angka simulasi perusahaan batu bara yang terdaftar di BEl, berapa potensi kenaikan atau penurunannya? Penelitian ini dilakukan melalui studi kepustakaan dengan menganalisis peraturan perundang-undangan dan simulasi data sekunder dengan pendekatan deskriptif kualitatif. Hasil penelitian menunjukkan bahwa dengan dimasukkannya batu bara sebagai BKP, justru berpotensi menyebabkan penurunan penerimaan negara, dengan nilai rata-rata per tahun sekitar 5,3 triliun rupiah. 


\section{PENDAHULUAN}

\subsection{Latar Belakang}

Secara konsepsional, Pajak Pertambahan Nilai (PPN) merupakan pajak yang dikenakan atas konsumsi Barang Kena Pajak (BKP) dan/atau Jasa Kena Pajak (JKP) di dalam daerah pabean (dalam negeri). Pengaturan mengenai objek PPN dapat dilihat pada Pasal 4, Pasal 16C, dan Pasal 16D UU Nomor 8 Tahun 1983 tentang Pajak Pertambahan Nilai dan Pajak atas Penjualan Barang Mewah sebagaimana telah diubah terakhir dengan UU Nomor 42 Tahun 2009 (UU PPN). Pada Pasal 4 UU PPN, terdapat delapan jenis objek PPN. Sementara pada Pasal Pasal 16C dan Pasal 16D, masing-masing terdapat satu objek PPN. Dengan demikian, setidaknya ada sepuluh jenis objek PPN menurut UU PPN.

Mengacu pada UU PPN, batu bara merupakan salah satu komoditas yang masuk dalam kategori non-BKP. Berdasarkan Pasal 4A ayat (2) huruf a UU PPN, termasuk barang yang bukan BKP adalah barang hasil pertambangan atau hasil pengeboran yang diambil langsung dari sumbernya. Selanjutnya, menurut penjelasan Pasal 4A ayat (2) huruf a poin e, termasuk barang hasil pertambangan atau hasil pengeboran yang diambil langsung dari sumbernya adalah batu bara sebelum diproses menjadi briket batu bara. Dengan demikian, menurut UU PPN, penyerahan batu bara tidak terutang PPN.

Namun demikian, dalam perkembangan terakhir, dengan telah diundangkannya Undang-Undang Nomor 11 Tahun 2020 tentang Cipta Kerja (UU Cipta Kerja), batu bara secara eksklusif dikeluarkan dari daftar negatif (negative list) Barang Kena Pajak (non-BKP). Berdasarkan Pasal 112 Kluster Perpajakan UU Cipta Kerja yang mengubah ketentuan Pasal 4A ayat (2) huruf a UU PPN, termasuk jenis barang yang tidak dikenai PPN adalah barang tertentu dalam kelompok barang hasil pertambangan atau pengeboran yang diambil langsung dari sumbernya, tidak termasuk hasil pertambangan batu bara. Dengan demikian, dengan mengacu pada ketentuan dalam UU Cipta Kerja, atas penyerahan batu bara oleh Pengusaha Kena Pajak menjadi terutang PPN.

Selintas dengan dimasukkannya batu bara sebagai BKP, yang oleh karenanya atas penyerahannya terutang PPN, akan berpotensi pada penambahan penerimaan negara (penerimaan pajak). Pendapat demikian setidaknya dikemukakan oleh Hendra Sinadia selaku Direktur Eksekutif Asosiasi Pertambangan Batu Bara Indonesia, yang menyatakan bahwa akar dari pengenaan PPN atas batu bara merupakan upaya pemerintah untuk meningkatkan penerimaan negara (Sembiring, 2020).

Berbeda dengan rumor atau isu atas jenis barang atau jasa lain yang menjadi wacana akan dikenai pajak (misalnya sembako dan jasa pendidikan), sejauh ini nyaris tidak pernah terdengar suara keberatan atau penolakan dari kalangan pengusaha batu bara atas dimasukkannya batu bara sebagai BKP dalam UU Cipta Kerja. Kuat dugaan bahwa ketiadaan resistensi dari kalangan pengusaha batu bara tersebut lebih disebabkan karena penjualan mereka yang berorientasi ekspor, dimana menurut Pasal 7 ayat (2) UU PPN tarif PPN terutangnya adalah nol persen (0\%). Batu bara merupakan komoditas yang sebagian besar dijual ke luar negeri (ekspor). Leonard (2019) menyampaikan data dari IHS Markit yang menyatakan bahwa Indonesia diprediksi masih menjadi eksportir terbesar batu bara hingga 2050.

Alih-alih terbebani dengan dimasukkannya batu bara sebagai BKP, para pengusaha batu bara justru berpotensi diuntungkan dengan adanya regulasi baru ini. Mengacu pada ketentuan Pasal 9 ayat (3) dan ayat (4) UU PPN, mekanisme pemungutan PPN di Indonesia menganut sistem indirect substraction. Dengan mekanisme ini, apabila dalam suatu Masa Pajak Pajak Keluaran lebih besar dari pada Pajak Masukan, selisihnya merupakan pajak kurang bayar yang harus dilunasi ke negara oleh pengusaha. Sebaliknya, jika Pajak Keluaran lebih kecil dari Pajak Masukan, selisihnya merupakan lebih bayar pajak, yang dapat diajukan kompensasi atau restitusi oleh pengusaha.

Salah satu kondisi yang berpotensi menyebabkan terjadinya PPN Lebih Bayar adalah apabila pengusaha melakukan ekspor BKP atau JKP. Kondisi demikian terjadi mengingat bahwa atas ekspor BKP dikenakan tarif PPN sebesar $0 \%$. Oleh karenanya secara matematis, status PPN bagi Pengusaha eksportir batu bara menjadi Lebih Bayar karena hasil pengurangan antara Pajak Keluaran yang nol rupiah (PPN dengan tarif 0\%) dan Pajak Masukan (yang dikenai tarif $10 \%$ ) adalah minus (lebih bayar).

Dengan mendasarkan pada ketentuan dalam UU PPN (sebelum diubah melalui UU Cipta Kerja), secara umum para pengusaha batu bara tidak dapat memenuhi kondisi PPN lebih bayar. Hal ini mengingat atas penyerahan (ekspor) batu bara masuk dalam kualifikasi penyerahan yang tidak terutang PPN. Dengan mengacu pada ketentuan dalam Pasal 9 ayat (8) UU PPN, apabila pengusaha melakukan penyerahan barang atau jasa yang tidak terutang, maka Pajak Masukan yang diperolehnya, tidak dapat dikreditkan. Dengan kata lain menurut ketentuan pengkreditan Pajak Masukan, terdapat perbedaan yang signifikan antara "penyerahan yang tidak terutang PPN" dan "penyerahan yang terutang PPN dengan tarif nol persen", meskipun secara nominal sama-sama memiliki implikasi sebesar 0 rupiah.

Sesungguhnya sebelum diundangkannya UU Cipta Kerja, ada juga kelompok pengusaha tambang batu bara yang masih dimungkinkan untuk memenuhi kondisi PPN Lebih bayar, yakni pengusaha pemegang Perjanjian Karya Pengusahaan Pertambangan Batu Bara (PKP2B) Generasi III, dimana batu bara merupakan BKP. Mengingat atas penyerahannya terutang PPN, maka Pajak Masukan dari para pengusaha pemegang PKP2P Generasi III, dapat dikreditkan. Dengan PPN terutang atas ekspor yang 0\%, secara matematis status PPN bagi Pemegang PKP2P pun menjadi lebih bayar.

Sebelum diundangkannya UU Cipta Kerja, memang terdapat perbedaan perlakuan PPN atas tambang batu bara terhadap pengusaha pemegang PKP2B Generasi I, II dan III. Hal ini disebabkan adanya perbedaan sifat dari masing-masing Generasi PKP2B terhadap ketentuan perpajakan, ada yang bersifat nailed down (berlaku 
tetap) dan ada yang prevailing law (mengikuti ketentuan yang berlaku).

Wisanggeni (2018) menyebutkan bahwa terdapat 10.922 Izin Usaha Pertambangan (IUP) di seluruh Indonesia dengan sebanyak 6.042 telah berstatus clean and clear (CNC) dan 4.880 sisanya berstatus non-CNC. Objek pajak yang terdapat dalam jenis usaha pertambangan tersebut utamanya adalah Pajak Pertambahan Nilai (PPN). Sebelum diproses menjadi briket batu bara, batu bara tidak dikenai PPN. Demikian halnya dengan batu bara sebagai hasil produksi melalui proses pengelolaan lebih lanjut berupa pemecahan, disliming, konsentrasi, dan penyaringan bahan galian sejak 1 Januari 2001 belum dapat diberlakukan sebagai Barang Kena Pajak (BKP).

Oleh karenanya, pengaturan PPN atas barang hasil tambang batu bara dalam UU Cipta Kerja ini juga dimaksudkan untuk menghadirkan pengaturan yang seragam bagi seluruh pengusaha tambang batu bara. Hal ini sebagaimana dikemukakan oleh Hestu Yoga Saksama (CNBC Indonesia, 12 Oktober 2020), "Selama ini dengan pengaturan batu bara sebelum menjadi briket, batu bara adalah non BKP (barang kena pajak), juga karena adanya pengaturan tersendiri melalui masing-masing PKP2B, maka terjadi perlakuan yang beragam untuk PPN atas batu bara. Oleh karena itu, untuk keseragaman dan kepastian hukum, batu bara ditetapkan menjadi BKP (barang kena pajak)."

Terlepas dari persoalan penyeragaman aturan, pengaturan dalam UU Cipta Kerja yang memasukkan batu bara sebagai BKP akan membawa konsekuensi terhadap penerimaan negara dari sektor PPN. Jika ditinjau dari aspek kewajiban pemungutan atas penyerahannya (karena telah dikualifisir sebagai BKP), tentu membawa konsekuensi pada kenaikan penerimaan negara. Namun sebaliknya jika ditinjau dari aspek pengkreditan Pajak Masukan (dimana Pajak Masukan pengusaha batu bara menjadi dapat dikreditkan) dan fakta bahwa batu bara merupakan produk berorientasi ekspor (dikenakan PPN nol persen), justru konsekuensi yang sangat mungkin adalah terjadinya PPN lebih bayar.

Mengacu pada Pasal 9 ayat (4), ayat (4a), ayat (4b) UU PPN, atas PPN lebih bayar tersebut oleh pengusaha tambang batu bara dapat diajukan kompensasi atau restitusi. Dengan demikian, adanya penormaan baru dalam UU Cipta Kerja yang memasukkan batu bara sebagai BKP, tidak serta merta membawa konsekuensi pada kenaikan penerimaan pajak, karena di dalamnya terkandung pula potensi PPN lebih bayar yang oleh dapat diajukan kompensasi atau bahkan restitusi yang berpotensi pada terjadinya penurunan penerimaan negara.

Sepengetahuan peneliti, sampai saat ini belum terdapat penelitian terkait potensi kenaikan atau penurunan penerimaan negara dari sektor PPN batu bara sebagai konsekuensi dimasukkannya batu bara sebagai BKP berdasarkan UU Cipta Kerja. Oleh karenanya, penelitian ini menjadi penting dan menarik untuk dilakukan.

\subsection{Pokok Permasalahan}

Berdasarkan hal-hal yang diuraikan dalam latar belakang, yang menjadi pokok permasalahan dalam penelitian ini adalah:

1) Dengan dimasukkannya batu bara sebagai Barang Kena Pajak berdasarkan UU Cipta Kerja, apakah otomatis memiliki konsekuensi pada kenaikan penerimaan negara atau justru sebaliknya penurunan pada penerimaan negara?

2) Melalui simulasi penghitungan Pajak Keluaran dikurangi Pajak Masukan dengan menggunakan data laporan keuangan perusahaan-perusahaan batu bara yang terdaftar di Bursa Efek Indonesia (BEI) tahun 2018-2020, berapa potensi kenaikan atau penurunan penerimaan negara yang akan terjadi?

\subsection{Batasan Penelitian}

Laporan keuangan yang digunakan dalam penghitungan potensi kenaikan atau penurunan penerimaan negara pada penelitian ini hanya meliputi perusahaan-perusahaan tambang batu bara yang telah go public (terdaftar di BEI) saja. Selain itu, besaran Pajak Keluaran dan Pajak Masukan yang digunakan dalam simulasi semata-mata hanya didasarkan pada akun-akun pendapatan dan beban atau biaya yang tersaji pada laporan keuangan, bukan data riil Pajak Keluaran dan Pajak Masukan.

\section{KERANGKA TEORI}

\subsection{Pengertian Pajak Pertambahan Nilai}

Pajak Pertambahan Nilai (PPN) adalah pajak yang dikenakan atas setiap pertambahan nilai dari barang atau jasa dalam peredarannya dari produsen ke konsumen. Wahono $(2012,264)$ mendefinisikan PPN sebagai pajak atas konsumsi barang dan jasa di daerah pabean yang dikenakan secara bertingkat di setiap jalur produksi dan distribusi.

Di Indonesia, tarif pembayaran PPN diatur oleh Pasal 7 UU Nomor 42 Tahun 2009 yang menyebutkan bahwa:

(1) Tarif Pajak Pertambahan Nilai adalah $10 \%$ (sepuluh persen).

(2) Tarif Pajak Pertambahan Nilai sebesar $0 \%$ (nol persen) diterapkan atas:

a. ekspor Barang Kena Pajak Berwujud;

b. ekspor Barang Kena Pajak Tidak Berwujud; dan

c. ekspor Jasa Kena Pajak.

(3) Tarif pajak sebagaimana dimaksud pada ayat (1) dapat diubah paling rendah $5 \%$ (lima persen) dan paling tinggi $15 \%$ (lima belas persen) yang perubahan tarifnya diatur dengan Peraturan Pemerintah.

\subsection{Karakteristik Pajak Pertambahan Nilai}

Menurut Waluyo (2011, 11), Pajak Pertambahan Nilai memiliki beberapa sifat pemungutan atau karakteristik yang dikenal dengan legal character sebagai berikut:

1) PPN merupakan pajak objektif; 
2) PPN merupakan pajak tidak langsung;

3) PPN bersifat multistage tax;

4) PPN dipungut dengan alat bukti Faktur Pajak;

5) PPN bersifat netral;

6) PPN tidak menimbulkan pajak ganda; dan

7) PPN merupakan pajak atas konsumsi Barang Kena Pajak dan/atau Jasa Kena Pajak di dalam daerah pabean (dalam negeri).

\subsection{Subjek Pajak Pertambahan Nilai}

Menurut Agustinus dan Kurniawan (2011, 8), subjek Pajak Pertambahan Nilai dapat diklasifikasikan menjadi dua, yaitu Pengusaha Kena Pajak dan Bukan Pengusaha Kena Pajak.

\subsection{Objek Pajak Pertambahan Nilai}

Pengaturan mengenai objek PPN dapat dilihat pada Pasal 4, Pasal 16C, dan Pasal 16D UU PPN. Dalam Pasal 4, dinyatakan bahwa Pajak Pertambahan Nilai dikenakan atas:

a. penyerahan Barang Kena Pajak di dalam Daerah Pabean yang dilakukan oleh pengusaha;

b. impor Barang Kena Pajak;

c. penyerahan Jasa Kena Pajak di dalam Daerah Pabean yang dilakukan oleh pengusaha;

d. pemanfaatan Barang Kena Pajak Tidak Berwujud dari luar Daerah Pabean di dalam Daerah Pabean;

e. pemanfaatan Jasa Kena Pajak dari luar Daerah Pabean di dalam Daerah Pabean;

f. ekspor Barang Kena Pajak Berwujud oleh Pengusaha Kena Pajak;

g. ekspor Barang Kena Pajak Tidak Berwujud oleh Pengusaha Kena Pajak; dan

h. ekspor Jasa Kena Pajak oleh Pengusaha Kena Pajak. Sementara itu, Pasal $16 \mathrm{C}$ mengatur mengenai objek PPN yang berupa kegiatan membangun sendiri. Pasal 16D memuat rincian mengenai penyerahan BKP berupa aktiva yang menurut tujuan semula tidak untuk diperjualbelikan oleh PKP, kecuali atas penyerahan aktiva yang Pajak Masukan-nya tidak dapat dikreditkan sebagaimana dimaksud dalam Pasal 9 ayat (8) huruf $b$ dan huruf $c$.

\subsection{Barang yang Dikecualikan dari Pengenaan Pajak Pertambahan Nilai}

Dalam Pasal 4A UU PPN, penggolongan barang yang tidak dikenakan PPN didasarkan atas kelompokkelompok barang sebagai berikut:

a. barang hasil pertambangan atau hasil pengeboran yang diambil langsung dari sumbernya;

b. barang kebutuhan pokok yang sangat dibutuhkan oleh rakyat banyak;

c. makanan dan minuman yang disajikan di hotel, restoran, rumah makan, warung, dan sejenisnya, meliputi makanan dan minuman baik yang dikonsumsi di tempat maupun tidak, termasuk makanan dan minuman yang diserahkan oleh usaha jasa boga atau katering; dan

d. uang, emas batangan, dan surat berharga.

Lebih lanjut, Pasal 7 PP Nomor 50 Tahun 1994, produk hukum turunan UU Nomor 8 Tahun 1983 yang mengalami perubahan pertama dengan UU Nomor 11 Tahun 1994, perubahan kedua dengan UU Nomor 18
Tahun 2000, dan terakhir dengan UU Nomor 42 Tahun 2009, menyatakan bahwa barang hasil pertambangan, penggalian, dan pengeboran yang diambil langsung dari sumbernya sebagaimana dimaksud dalam Pasal 3, meliputi:

1. minyak mentah;

2. gas bumi;

3. pasir dan kerikil;

4. barang hasil pertambangan, penggalian, pengeboran lainnya yang diambil langsung dari sumbernya.

Perubahan jenis barang tambang yang tidak dikenakan PPN kembali diatur sangat jelas untuk batu bara sebelum diproses menjadi briket batu bara. Dalam Pasal 1 huruf a PP Nomor 144 Tahun 2000 tentang Jenis Barang dan Jasa yang Tidak Dikenakan PPN, barang hasil pertambangan atau hasil pengeboran yang diambil langsung dari sumbernya termasuk dalam kelompok barang yang tidak dikenakan PPN. Ketentuan tersebut diperjelas pada Pasal 2 yang menyebutkan bahwa jenis barang hasil pertambangan atau hasil pengeboran yang diambil langsung dari sumbernya sebagaimana dimaksud dalam Pasal 1 huruf a adalah:

a. minyak mentah;

b. gas bumi;

c. panas bumi;

d. pasir dan kerikil;

e. batu bara sebelum diproses menjadi briket batu bara; dan

f. bijih besi, bijih timah, bijih emas, bijih tembaga, bijih nikel, dan bijih perak serta bijih bauksit.

\subsection{Pajak Masukan dan Pajak Keluaran}

Secara umum, Pajak Pertambahan Nilai (PPN) terdiri dari dua komponen yaitu Pajak Masukan dan Pajak Keluaran. Menurut Gustian dan Lubis (2011, 101), Pajak Keluaran adalah Pajak Pertambahan Nilai terutang yang wajib dipungut oleh Pengusaha Kena Pajak yang melakukan penyerahan Barang Kena Pajak, penyerahan Jasa Kena Pajak, ekspor Barang Kena Pajak berwujud, ekspor Barang Kena Pajak tidak berwujud, dan/atau ekspor Jasa Kena Pajak. Berdasarkan Pasal 1 ayat (24) UU PPN, Pajak Masukan adalah Pajak Pertambahan Nilai yang seharusnya sudah dibayar oleh Pengusaha Kena Pajak karena perolehan Barang Kena Pajak dan/atau penerimaan Jasa Kena Pajak, pemanfaatan Jasa Kena Pajak dari luar Daerah Pabean, atau impor Barang Kena Pajak.

\subsection{Restitusi}

Pasal 9 ayat (4) UU PPN menyatakan bahwa "apabila dalam suatu Masa Pajak, Pajak Masukan yang dapat dikreditkan lebih besar daripada Pajak Keluaran, selisihnya merupakan kelebihan pajak yang dikompensasikan ke Masa Pajak berikutnya." Dalam Lembaran Negara Republik Indonesia Tahun 2009 Nomor 150, dijelaskan bahwa kelebihan Pajak Masukan dalam suatu Masa Pajak sesuai dengan ketentuan pada ayat (4) dikompensasikan pada Masa Pajak berikutnya. Namun, apabila kelebihan Pajak Masukan terjadi pada Masa Pajak akhir tahun buku, kelebihan Pajak Masukan tersebut dapat diajukan permohonan pengembalian (restitusi). 
Menurut PP Nomor 3 Tahun 2002 Pasal 1 angka 5 restitusi adalah ganti kerugian yang diberikan kepada korban atau keluarganya oleh pelaku atau pihak ketiga, dapat berupa pengembalian harta milik, pembayaran ganti kerugian untuk kehilangan atau penderitaan, atau penggantian biaya untuk tindakan tertentu. Djuanda \& Lubis $(2011,121)$ menyatakan bahwa restitusi merupakan kelebihan pembayaran Pajak Pertambahan Nilai yang terjadi karena jumlah Pajak Masukan yang dibayar lebih besar daripada jumlah Pajak Keluaran yang dipungut dalam suatu Masa Pajak.

\subsection{Penerimaan Perpajakan}

Menurut Undang-Undang Nomor 9 Tahun 2020 tentang Anggaran Pendapatan dan Belanja Negara Tahun Anggaran 2020 Pasal 1 angka 3, penerimaan perpajakan mencakup semua penerimaan negara yang terdiri atas pajak dalam negeri dan pajak perdagangan internasional. Adapun menurut Amir \& Hastiadi (2016, 143), penerimaan perpajakan merupakan kontributor dominan dalam penerimaan negara setiap tahunnya.

\section{METODE PENELITIAN}

Metode yang digunakan dalam penelitian ini adalah studi kepustakaan melalui analisis data sekunder dengan pendekatan deskriptif kualitatif. Pengukuran potensi kenaikan atau penurunan PPN dilakukan melalui pembuatan simulasi pengurangan Pajak Keluaran dengan Pajak Masukan dengan menggunakan data laporan keuangan perusahaan batu bara yang terdaftar di Bursa Efek Indonesia (BEI).

\section{HASIL PENELITIAN}

\subsection{Total Penjualan dan Total Beban Perusahaan Batu Bara dalam Laporan Laba Rugi}

Tabel IV.1 menunjukkan total penjualan batu bara tiap perusahaan dalam tahun 2018-2020 yang nilainya telah dikonversikan ke dalam mata uang Rupiah sesuai dengan kurs yang berlaku pada tanggal transaksi dan/atau tanggal pelaporan. Penghitungan Pajak Keluaran dilakukan melalui hasil perkalian antara total penjualan ekspor batu bara yang kemudian dikalikan dengan tarif $0 \%$.

Tabel IV.1 Total Penjualan Batu Bara Berdasarkan Segmen Geografis (dalam juta Rupiah)

\begin{tabular}{|c|c|c|c|c|c|c|c|}
\hline \multirow[t]{2}{*}{ Entitas } & \multirow{2}{*}{$\begin{array}{l}\text { Tujuan } \\
\text { Pemasaran }\end{array}$} & \multicolumn{3}{|c|}{ Total Penjualan } & \multicolumn{3}{|c|}{$\begin{array}{l}\text { Persentase terhadap } \\
\text { Total Penjualan } \\
\end{array}$} \\
\hline & & 2020 & 2019 & 2018 & 2020 & 2019 & 2018 \\
\hline \multirow{2}{*}{ ADRO } & Domestik & $7.557,2$ & $8.441,8$ & $9.214,7$ & $23 \%$ & $19 \%$ & $19 \%$ \\
\hline & Ekspor & $25.362,5$ & $35.398,7$ & $39.253,3$ & $77 \%$ & $81 \%$ & $81 \%$ \\
\hline \multirow{2}{*}{ BYAN } & Domestik & $2.508 .338,1$ & $1.660 .091,3$ & $3.196 .615,3$ & $13 \%$ & $9 \%$ & $13 \%$ \\
\hline & Ekspor & $17.169 .734,5$ & $17.684 .399,0$ & $21.083 .927,8$ & $87 \%$ & $91 \%$ & $87 \%$ \\
\hline \multirow{2}{*}{ ITMG } & Domestik & $3.700,7$ & \begin{tabular}{ll|}
$4.105,9$ \\
\end{tabular} & $4.472,5$ & $21 \%$ & $17 \%$ & $16 \%$ \\
\hline & Ekspor & $13.572,0$ & $20.162,8$ & $24.136,3$ & $79 \%$ & $83 \%$ & $84 \%$ \\
\hline \multirow{2}{*}{ MBAP } & Domestik & $160.180,2$ & $415.093,0$ & $69.004,6$ & $5 \%$ & $11 \%$ & $2 \%$ \\
\hline & Ekspor & $2.772 .818,4$ & $3.274 .888,3$ & $3.608 .429,8$ & $95 \%$ & $89 \%$ & $98 \%$ \\
\hline \multirow{2}{*}{ PTBA } & Domestik & $9.587 .277,0$ & $12.888 .125,0$ & $10.970 .781,0$ & $55 \%$ & $59 \%$ & $52 \%$ \\
\hline & Ekspor & $7.737 .915,0$ & $8.899 .439,0$ & $10.196 .212,0$ & $45 \%$ & $41 \%$ & $48 \%$ \\
\hline \multirow{2}{*}{ GEMS } & Domestik & $6.028 .394,1$ & $4.898 .664,0$ & $\begin{array}{l}4.904 .625,7 \\
\end{array}$ & $40 \%$ & $32 \%$ & 32 \\
\hline & Ekspor & $8.921 .040,8$ & $10.482 .781,8$ & $10.241 .149,9$ & $60 \%$ & $68 \%$ & $68 \%$ \\
\hline \multirow{2}{*}{ HRUM } & Domestik & $160.436,6$ & $201.847,1$ & $207.722,1$ & $7 \%$ & $5 \%$ & \\
\hline & Ekspor & $2.094 .121,2$ & $3.549 .448,2$ & 4.602.389,1 & $93 \%$ & $95 \%$ & $96 \%$ \\
\hline
\end{tabular}

Sumber: Data Sekunder yang Diolah

Secara garis besar, porsi penjualan ekspor jauh lebih tinggi dibandingkan dengan penjualan domestik. Meskipun penjualan batu bara PTBA berdasarkan segmen geografis cenderung seimbang, tetapi porsi penjualan ekspor dari mayoritas perusahaan mencapai 70\%-90\% dari total penjualan secara keseluruhan.

Sementara itu, perkiraan dari nilai Pajak Masukan diperoleh dari total beban perusahaan di dalam Laporan Laba Rugi yang kemudian dikenakan tarif PPN sebesar $10 \%$. Tabel IV. 2 menunjukkan total beban yang dikeluarkan tiap perusahaan selama tahun 2018-2020 yang nilainya telah dikonversikan ke dalam mata uang Rupiah sesuai dengan kurs yang berlaku pada tanggal transaksi dan/atau tanggal pelaporan.

Tabel IV.2 Total Beban Perusahaan Batu Bara dalam Laporan Laba Rugi (dalam juta Rupiah)

\begin{tabular}{|l|r|r|r|}
\hline \multirow{2}{*}{$\begin{array}{c}\text { Nama } \\
\text { Perusahaan }\end{array}$} & \multicolumn{3}{|c|}{ Total Beban } \\
\cline { 2 - 4 } & $\mathbf{2 0 2 0}$ & \multicolumn{1}{|c|}{$\mathbf{2 0 1 9}$} & \multicolumn{1}{c|}{$\mathbf{2 0 1 8}$} \\
\hline ADRO & $33.972,5$ & $43.472,9$ & $45.881,4$ \\
\hline BYAN & $17.323 .335,3$ & $16.157 .930,8$ & $16.777 .910,6$ \\
\hline ITMG & $16.765,0$ & $22.576,6$ & $24.990,6$ \\
\hline MBAP & $2.596 .536,4$ & $3.223 .526,7$ & $2.982 .691,0$ \\
\hline PTBA & $15.847 .438,0$ & $18.481 .675,0$ & $17.059 .246,0$ \\
\hline GEMS & $13.790 .547,9$ & $14.623 .202,4$ & $13.829 .864,5$ \\
\hline HRUM & $2.251 .930,5$ & $3.548 .072,4$ & $4.321 .132,4$ \\
\hline
\end{tabular}

Sumber: Data Sekunder yang Diolah

\subsection{Simulasi Penghitungan Potensi PPN Kurang atau (Lebih) Bayar Tahun 2018 s.d. 2020}

Tabel IV.3 merupakan hasil simulasi penghitungan potensi PPN Kurang atau (Lebih) Bayar, yang dilakukan dengan menggunakan mekanisme indirect substraction method (Pajak Keluaran dikurangi Pajak Masukan), sebagaimana dianut dalam UU PPN.

Tabel IV.3 Simulasi Penghitungan Potensi PPN Kurang atau (Lebih) Bayar Tahun 2018 s.d. 2020 (dalam jutaan Rupiah)

\begin{tabular}{|c|c|c|c|c|c|c|}
\hline \multirow{2}{*}{ Entitas } & \multirow{2}{*}{ Tahun } & \multirow{2}{*}{$\begin{array}{c}\text { Penjualan } \\
\text { Total }\end{array}$} & \multirow{2}{*}{$\begin{array}{l}\text { PK } \\
0 \% \\
\end{array}$} & \multirow{2}{*}{$\begin{array}{c}\text { Pembelian } \\
\text { Total }\end{array}$} & \multirow{2}{*}{$\begin{array}{l}\mathrm{PM} \\
10 \%\end{array}$} & \multirow{2}{*}{$\begin{array}{c}\text { PPN Lebih } \\
\text { Bayar }\end{array}$} \\
\hline & & & & & & \\
\hline \multirow[t]{3}{*}{ ADRO } & 2020 & $25.362,5$ & 0 & $33.972,5$ & $3.397,25$ & $3.397,25$ \\
\hline & 2019 & $35.398,7$ & 0 & $43.472,9$ & $4.347,29$ & $4.347,29$ \\
\hline & 2018 & $39.253,3$ & 0 & $45.881,4$ & $4.588,14$ & $4.588,14$ \\
\hline \multirow[t]{3}{*}{ BYAN } & 2020 & $17.169 .734,5$ & 0 & $17.323 .335,3$ & $1.732 .333,53$ & $1.732 .333,53$ \\
\hline & 2019 & $17.684 .399,0$ & 0 & $16.157 .930,8$ & $1.615 .793,08$ & $1.615 .793,08$ \\
\hline & 2018 & $21.083 .927,8$ & 0 & $16.777 .910,6$ & $1.677 .791,06$ & $1.677 .791,06$ \\
\hline \multirow[t]{3}{*}{ ITMG } & 2020 & $13.572,0$ & 0 & $16.765,0$ & $1.676,50$ & $1.676,50$ \\
\hline & 2019 & $20.162,8$ & 0 & $22.576,6$ & $2.257,66$ & $2.257,66$ \\
\hline & 2018 & $24.136,3$ & 0 & $24.990,6$ & $2.499,06$ & $2.499,06$ \\
\hline \multirow[t]{3}{*}{ MBAP } & 2020 & $2.772 .818,4$ & 0 & $2.596 .536,4$ & $259.653,64$ & $259.653,64$ \\
\hline & 2019 & $3.274 .888,3$ & 0 & $3.223 .526,7$ & $322.352,67$ & $322.352,67$ \\
\hline & 2018 & $3.608 .429,8$ & 0 & $2.982 .691,0$ & $298.269,10$ & $298.269,10$ \\
\hline \multirow[t]{3}{*}{ PTBA } & 2020 & $7.737 .915,0$ & 0 & $15.847 .438,0$ & $1.584 .743,80$ & $1.584 .743,80$ \\
\hline & 2019 & $8.899 .439,0$ & 0 & $18.481 .675,0$ & $1.848 .167,50$ & $1.848 .167,50$ \\
\hline & 2018 & $10.196 .212,0$ & 0 & $17.059 .246,0$ & $1.705 .924,60$ & $1.705 .924,60$ \\
\hline \multirow[t]{3}{*}{ GEMS } & 2020 & $8.921 .040,8$ & 0 & $13.790 .547,9$ & $1.379 .054,79$ & $1.379 .054,79$ \\
\hline & 2019 & $10.482 .781,8$ & 0 & $14.623 .202,4$ & $1.462 .320,24$ & $1.462 .320,24$ \\
\hline & 2018 & $10.241 .149,9$ & 0 & $13.829 .864,5$ & $1.382 .986,45$ & $1.382 .986,45$ \\
\hline \multirow{3}{*}{ HRUM } & 2020 & $2.094 .121,2$ & 0 & $2.251 .930,5$ & $225.193,05$ & $225.193,05$ \\
\hline & 2019 & $3.549 .448,2$ & 0 & $3.548 .072,4$ & $354.807,24$ & $354.807,24$ \\
\hline & 2018 & 4.602.389,1 & 0 & 4.321.132,4 & $432.113,24$ & $432.113,24$ \\
\hline \multirow{3}{*}{ TOTAL } & \multicolumn{5}{|c|}{2020} & $5.186 .052,55$ \\
\hline & \multirow{2}{*}{\multicolumn{5}{|c|}{$\frac{2019}{2018}$}} & $5.610 .045,68$ \\
\hline & & & & & & $5.504 .171,65$ \\
\hline & \multicolumn{5}{|c|}{2018} & $16.300 .269,88$ \\
\hline
\end{tabular}

Sumber: Data Sekunder yang Diolah

Simulasi penghitungan pada tabel Tabel IV. 3 di atas menunjukkan adanya potensi PPN Lebih Bayar. Secara berturut-turut, total nilai PPN Lebih Bayar untuk seluruh perusahaan dalam tahun 2018-2020 adalah sebesar Rp5.504.171.650.000; Rp5.610.045.680.000; dan Rp5.186.052.550.000 atau rata-rata per tahun sebesar Rp5.433.423.000 (5,433 triliun rupiah). Secara keseluruhan, total potensi PPN Lebih Bayar selama tiga tahun (2018-2020) adalah sebesar Rp16.300.269.880.000 atau sekitar 16,3 trilun rupiah. 
Adapun rincian singkat penghitungan potensi PPN Lebih) Bayar pada masing-masing perusahaan adalah sebagai berikut:

1) PT Adaro Energy Tbk (ADRO)

- Tahun 2018: Rp4.588.140.000

- Tahun 2019: Rp4.347.290.000

- Tahun 2020: Rp3.397.250.000

2) PT Bayan Resources Tbk (BYAN)

- Tahun 2018: Rp1.677.791.060.000

- Tahun 2019: Rp1.615.793.080.000

- Tahun 2020: Rp1.732.333.530.000

3) PT Indo Tambangraya Megah Tbk (ITMG)

- Tahun 2018: Rp2.499.060.000

- Tahun 2019: Rp2.257.660.000

- Tahun 2020: Rp1.676.500.000

4) PT Mitrabara Adiperdana Tbk (MBAP)

- Tahun 2018: Rp298.269.100.000

- Tahun 2019: Rp322.352.670.000

- Tahun 2020: Rp322.352.670.000

5) PT Bukit Asam Tbk (PTBA)

- Tahun 2018: Rp1.705.924.600.000

- Tahun 2019: Rp1.848.167.500.000

- Tahun 2020: Rp1.584.743.800.000

6) PT Golden Energy Mines Tbk (GEMS)

- Tahun 2018: Rp1.382.986.450.000

- Tahun 2019: Rp1.462.320.240.000

- Tahun 2020: Rp1.379.054.790.000

7) PT Harum Energy Tbk (HRUM)

- Tahun 2018: Rp432.113.240.000

- Tahun 2019: Rp354.807.240.000

- Tahun 2020: Rp225.193.050.000

\section{KESIMPULAN}

Kesimpulan dari penelitian ini adalah:

1) Dengan dimasukkannya batu bara sebagai jenis Barang Kena Pajak berdasarkan UU Cipta Kerja, tidak otomatis atau serta merta berpotensi pada kenaikan penerimaan negara dari sektor PPN. Data menunjukkan bahwa dengan batu bara menjadi BKP, justru berpotensi pada penurunan penerimaan negara akibat restitusi yang dapat diajukan oleh pengusaha tambang batu bara. Hal ini diungkinkan terjadi mengingat bahwa batu bara merupakan komoditas yang berorientasi ekspor (dikenakan PPN dengan tarif nol persen), dan Pajak Masukan pengusaha batu bara yang sebelumnya tidak dapat dikreditkan, menjadi dapat dikreditkan.

2) Dari simulasi penghitungan dengan menggunakan data laporan keuangan tujuh perusahaan batu bara yang terdaftar d BEI tahun 2018-2020, terdapat potensi penurunan penerimaan negara sebagai akibat pengajuan restitusi atas PPN Lebih Bayar, sebesar:

- Tahun 2018: Rp5.504.171.650.000

- Tahun 2019: Rp5.610.045.680.000

- Tahun 2020: Rp5.186.052.550.000

\section{DAFTAR PUSTAKA (REFERENCES)}

Agustinus, S., \& Kurniawan, I. (2011). Faktur pajak dan SPT Masa PPN. Yogyakarta: Penerbit Andi.
Djuanda, G., \& Lubis, I. (2011). Pelaporan pajak pertambahan nilai dan pajak penjualan atas barang mewah. Jakarta: PT Gramedia Pustaka Utama.

Leonard, L. (2019, Mei 27). Indonesia Rajai Pasar Ekspor Batu Bara. Bisnis.com: https://ekonomi.bisnis.com/read/20190527/4 4/927982/indonesia-rajai-pasar-ekspor-batubara

Nazir, M. (2005). Metode Penelitian. Bogor: Ghalia Indonesia.

Sembiring, L. J. (2020, Oktober 12). Terungkap! Ini Alasan Kenapa Pemerintah Kenakan PPN Batu Bara. InBC Indonesia: https://www.cnbcindonesia.com/news/20201 012184128-4-193778/terungkap-ini-alasankenapa-pemerintah-kenakan-ppn-batu-bara

Undang-Undang Nomor 42 Tahun 2009 tentang Perubahan Ketiga atas Undang-Undang Nomor 8 Tahun 1983 tentang Pajak Pertambahan Nilai Barang dan Jasa dan Pajak Penjualan atas Barang Mewah.

Undang-Undang Nomor 3 Tahun 2020 tentang Perubahan atas Undang-Undang Nomor 4 Tahun 2009 tentang Pertambangan Mineral dan Batu Bara.

Undang-Undang Nomor 9 Tahun 2020 tentang Anggaran Pendapatan dan Belanja Negara Tahun Anggaran 2020.

Undang-Undang Nomor 11 Tahun 2020 tentang Cipta Kerja.

Wahono, S. (2012). Teori dan aplikasi: Mengurus pajak itu mudah. Jakarta: Elex Media Komputindo.

Waluyo. (2011). Perpajakan Indonesia edisi 10 buku 2. Jakarta: Penerbit Salemba Empat.

Wisanggeni, I. (2018). PPN pada sektor industri khusus. Jakarta: Mitra Wacana Media. 